\title{
REVIEW
}

\section{REVISED Autophagy and airway fibrosis: Is there a link? [version}

\section{2; peer review: 3 approved]}

\author{
Anudeep Kota1-3, Deepak A. Deshpande ${ }^{4}$, Mehra Haghi3 ${ }^{3}$ Brian Oliver ${ }^{1,2}$, \\ Pawan Sharma (iD) 1,2
}

\author{
${ }^{1}$ Faculty of Science, University of Technology Sydney, Sydney, NSW, 2007, Australia \\ 2Woolcock Emphysema Centre, Woolcock Institute of Medical Research, The University of Sydney, Sydney, NSW, 2037, Australia \\ ${ }^{3}$ Graduate School of Health, University of Technology Sydney, Sydney, NSW, 2007, Australia \\ ${ }^{4}$ Centre for Translational Medicine, Thomas Jefferson University, Philadelphia, PA, 19107, USA
}

V2 First published: 03 Apr 2017, 6:409

https://doi.org/10.12688/f1000research.11236.1

Latest published: 11 Jun 2018, 6:409

https://doi.org/10.12688/f1000research.11236.2

\section{Abstract}

In the past decade, an emerging process named "autophagy" has generated intense interest in many chronic lung diseases. Tissue remodeling and fibrosis is a common feature of many airway diseases, and current therapies do not prevent or reverse these structural changes. Autophagy has evolved as a conserved process for bulk degradation and recycling of cytoplasmic components to maintain basal cellular homeostasis and healthy organelle populations in the cell. Furthermore, autophagy serves as a cell survival mechanism and can also be induced by chemical and physical stress to the cell. Accumulating evidence demonstrates that autophagy plays an essential role in vital cellular processes, including tissue remodeling. This review will discuss some of the recent advancements made in understanding the role of this fundamental process in airway fibrosis with emphasis on airway remodeling, and how autophagy can be exploited as a target for airway remodeling in asthma and chronic obstructive pulmonary disease.

Keywords

asthma, COPD, airway remodeling, airway mesenchymal cells

\section{Open Peer Review}

$\begin{array}{rrr}\text { Approval Status } & \checkmark \checkmark \\ 1 & 2 & 3\end{array}$

\section{version 2}

(revision)

11 Jun 2018

version 1

03 Apr 2017

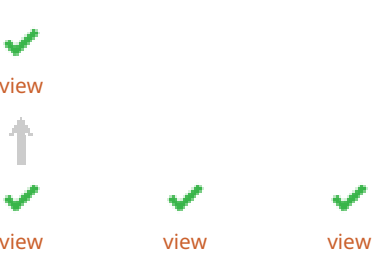

1. Eugene Roscioli, University of Adelaide,

Adelaide, Australia

2. Kimberley C.W. Wang, Telethon Kids Institute, Subiaco, Australia

3. Sukhwinder Singh Sohal ID, University of

Tasmania, Launceston, Australia

Any reports and responses or comments on the article can be found at the end of the article. 
Corresponding author: Pawan Sharma (pawan.sharma@uts.edu.au)

Author roles: Kota A: Writing - Original Draft Preparation; Deshpande DA: Writing - Review \& Editing; Haghi M: Writing - Review \& Editing; Oliver B: Writing - Review \& Editing; Sharma P: Conceptualization, Writing - Original Draft Preparation

Competing interests: No competing interests were disclosed.

Grant information: This work was supported by the Centre for Health Technologies, Chancellors Fellowship Research Program, the National Institute of Health, and the National Health and Medical Research Council.

The funders had no role in study design, data collection and analysis, decision to publish, or preparation of the manuscript.

Copyright: $\odot 2018$ Kota A et al. This is an open access article distributed under the terms of the Creative Commons Attribution License, which permits unrestricted use, distribution, and reproduction in any medium, provided the original work is properly cited. Data associated with the article are available under the terms of the Creative Commons Zero "No rights reserved" data waiver (CC0 1.0 Public domain dedication).

How to cite this article: Kota $\mathrm{A}$, Deshpande DA, Haghi $\mathrm{M}$ et al. Autophagy and airway fibrosis: Is there a link? [version 2; peer review: 3 approved] F1000Research 2018, 6:409 https://doi.org/10.12688/f1000research.11236.2

First published: $03 \mathrm{Apr}$ 2017, 6:409 https://doi.org/10.12688/f1000research.11236.1 


\section{REVISED Amendments from Version 1}

In the revised version we have addressed the comments and suggestions made by the reviewers. Particularly we have added some text on role of autophagy in EMT and its potential link with airway remodeling in COPD. We have modified the Figure 2 and have added a link between circadian rhythm and autophagy and its potential impact on airway fibrosis. Further we have now updated references as suggested by the reviewers. The revised version has enhanced the quality of the review keeping the message focussed.

See referee reports

\section{Introduction}

Autophagy is an evolutionarily conserved pathway for the turnover of organelles and proteins by lysosomal-dependent processing ${ }^{1}$. During autophagy, newly formed double-membrane structures, called autophagosomes, encapsulate cytoplasmic material, such as dysfunctional or damaged organelles or proteins. The autophagosomes then fuse with lysosomes, thus delivering the sequestered cargo for lysosomal-dependent degradation ${ }^{2}$, as described in Figure 1. In the last decade, autophagy has emerged as a fundamental process involved in tissue and cellular homeostasis, and thus has been implicated in maintaining basal physiologic (healthy) and adaptive pathophysiologic responses

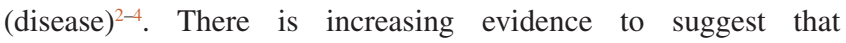
autophagy can impact the pathogenesis and/or progression of many human diseases ${ }^{2,4,5}$, including neurodegenerative diseases ${ }^{6}$, cancer $^{7}$, heart diseases ${ }^{8,9}$ and immune disorders (reviewed in 3,10).
Fibrotic airway remodeling remains a key pathological feature correlating with a decline in lung function and disease progression in both asthma and chronic obstructive pulmonary disease (COPD) patients ${ }^{1-13}$. While there is no treatment for preventing development of airway remodeling, cell fate phenomena, such as autophagy, have been shown to play a role in asthma and COPD pathogenesis. Here, we review the progress in understanding how autophagy can contribute to airway fibrosis and the emerging strategies to target this process for therapeutic benefit.

\section{Evidence of autophagy in asthma}

Asthma is a chronic inflammatory disease of the lungs, characterized by airway inflammation, airway hyperresponsiveness and tissue remodeling. It affects more than 300 million people worldwide and this number is estimated to escalate to 400 million by $2025^{14}$.

The role of autophagy in pulmonary diseases has gained attention in the past decade, but only very few studies have described the role of autophagy in asthma. One of the very first studies that described a direct role between asthma and autophagy revealed the association of the ATG5 gene in the pathogenesis of asthma ${ }^{15}$. This study found a genetic association in 1338 adult patients with asthma and the expression of the autophagy gene ATG5. ATG5 encodes the ATG5 protein of 276 amino acids. During autophagy, the ATG5 protein interacts with ATG12 and ATG16 to form a ATG12-ATG5-ATG16 complex. This complex is associated with autophagosomal membrane elongation by interaction with ATG3, leading to ATG8-phosphatidyl ethanolamine formation ${ }^{16}$. This

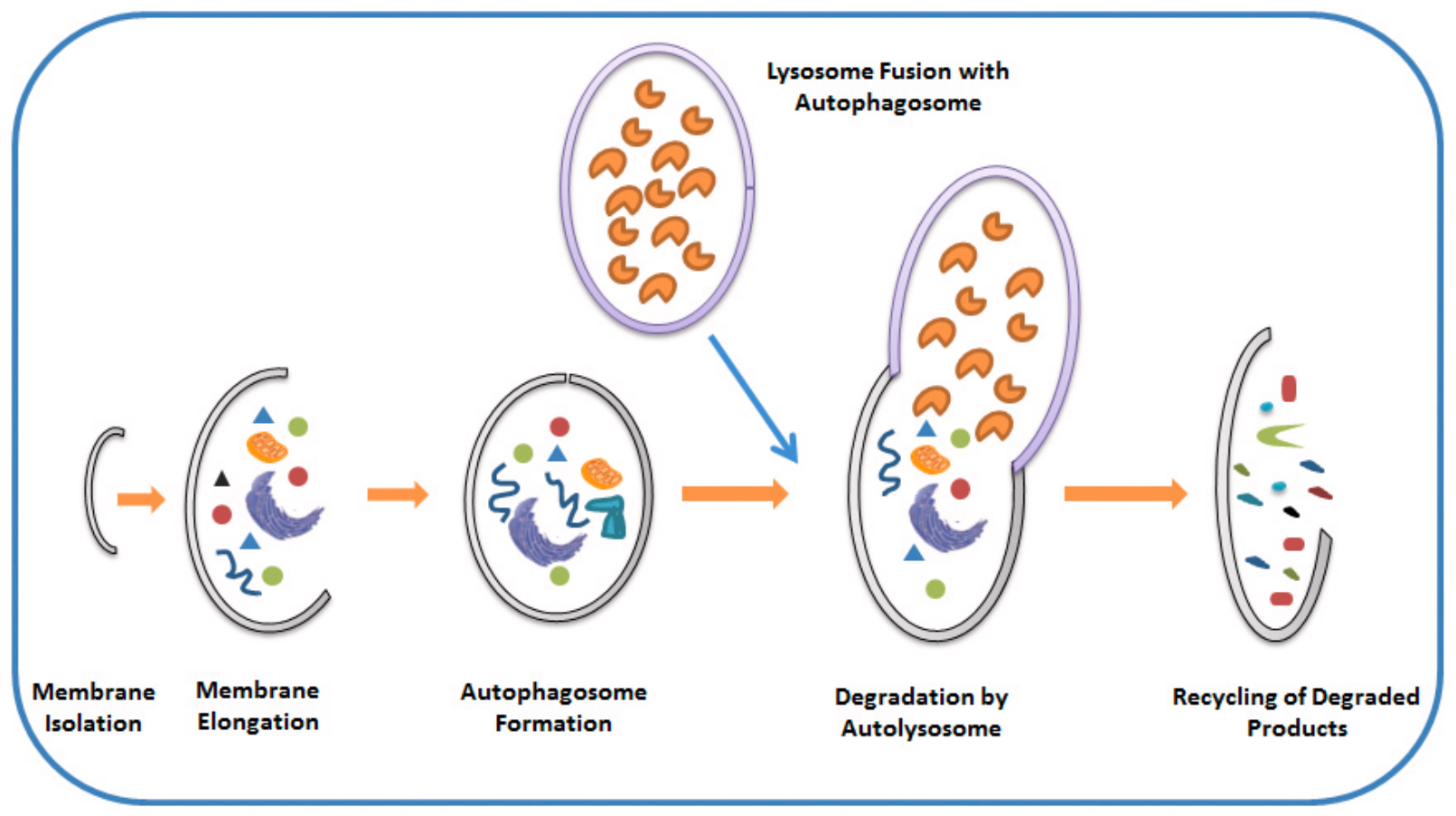

Figure 1. Pictorial representation of the autophagy pathway. The autophagy pathway proceeds through several phases, including initiation (formation of a preautophagosomal structure leading to an isolation membrane, or phagophore), vesicle elongation, autophagosome maturation and cargo sequestration, and autophagosome-lysosome fusion. In the final stage, autophagosomal contents are degraded by Iysosomal acid hydrolases and the contents of the autolysosome are released for metabolic recycling. 
association was further validated in another study with 312 asthmatic and 246 control children, which showed that genetic variants in ATG5 are associated with pathogenesis of childhood asthma ${ }^{17,18}$. Furthermore, a study by Poon et al. revealed the role of ATG5 in adult asthma, and also found an increased number of autophagosomes in fibroblast and epithelial cells from severe asthmatics when compared to healthy volunteers ${ }^{16}$. Recent studies show that there is emerging evidence for the role of autophagy in both eosinophilic ${ }^{19}$ and neutrophilic asthma ${ }^{20}$, and convey its link to severe asthma and fibrotic tissue remodeling.

A recent study by Ban et al. investigated the role of autophagy in sputum granulocytes, peripheral blood cells and peripheral blood eosinophils of severe and non-severe asthmatics ${ }^{21}$. They found increased autophagy in the immune cells from the severe asthmatics when compared to non-severe and healthy controls. This clearly indicates that induction of autophagy in immune cells is associated with severe asthma. By contrast, a study conducted by Akbari's group reveals the induction of neutrophilic airway inflammation and hyperreactivity on deletion of CD11 cell specific ATG5 mice. In addition, in this study augmented neutrophilic inflammation in $\operatorname{Atg} 5(-/-)$ mice is IL-17A driven and glucocorticoid resistant ${ }^{22}$.

In our own hands, we have found increased signatures of key autophagy genes in the lungs of asthmatic patients when compared with non-asthmatics, suggesting that basal autophagy is higher in asthma (unpublished data). Furthermore, we also found increased expression of autophagy proteins in the lung tissue obtained from chronic mouse model of HDM-induced asthma and this expression was found to correlate with pro-fibrotic signaling (Smad) and extracellular matrix protein (collagen) in the lung (unpublished data).

These data suggest that autophagy and airway fibrosis occur together with allergic insult, and act as a key driver for airway remodeling in allergic asthma. The current literature clearly indicates that the autophagy-phenomenon may be a crucial driver in the pathogenesis of asthma, particularly in severe forms of the disease, with an unknown underlying mechanism. The therapeutic modulation of autophagy with novel inhibitors may lead to the development of a new class of drugs for severe asthma.

\section{Evidence of autophagy in COPD}

COPD is a progressive lung disease characterized by accelerated decline in lung function over time. Its most common pathological feature includes emphysema and chronic bronchitis. Airway obstruction in COPD in associated with formation of peribronchial fibrosis, increased wall thickness and excess mucus secretion, especially in the smaller airways ${ }^{23}$. Exposure to cigarette smoke is one major cause of COPD; however only $25 \%$ of smokers develop COPD, which suggests the existence of numerous other factors contributing to COPD (such as genetic predisposition and oxidative stress $)^{24,25}$. The role of autophagy in COPD seems to be more complex than anticipated, as some studies showed its impairment ${ }^{26-28}$, while others suggest it facilitates disease pathogenesis ${ }^{29-32}$. More recently, the role of selective autophagy (such as mitophagy, ciliophagy and xenophagy) in COPD pathology has been proposed ${ }^{32}$.
The very first demonstration of autophagy in COPD was shown by Chen et al., where authors found increased autophagy markers in the lungs of COPD patients ${ }^{29}$. The authors also found a similar expression of elevated autophagy markers at various stages of the disease. This suggests that altered autophagy could be a key regulator in the pathogenesis and progression of COPD. The same study also showed that the autophagy marker LC3II/LC3I was significantly increased in lungs from patients with $\alpha-1$ antitrypsin deficiency when compared with non-COPD donors ${ }^{29}$. In addition, many other studies have shown the increased expression of autophagy markers both in vitro and in vivo when exposed to cigarette smoke extract ${ }^{17,29,30,33}$, which explains increased loss of alveolar epithelial cells as seen in emphysema.

Moreover, to investigate the role of autophagy in chronic bronchitis, Lam and colleagues demonstrated that induction of autophagy leads to shortening of cilia in mouse tracheal epithelial cells exposed to cigarette smoke ${ }^{31}$. They further found that autophagy gene deficient mice $\left(\mathrm{Becn} 1^{+/-}\right.$or Map1lc3B $\mathrm{B}^{-/}$) were resistant to the shortening of cilia in tracheal epithelial cells when exposed to cigarette smoke, demonstrating a direct role of autophagy in this process $^{31}$. Recent studies have demonstrated that selective autophagy (namely mitophagy) plays an important role in regulating mitochondrial function, which in turn has a crucial role in COPD pathogenesis ${ }^{34}$. However, the specific role of mitophagy in tissue injury mediated by cigarette smoke remains obscure and requires further study ${ }^{32}$.

Overall, autophagy plays a key role in COPD pathogenesis, especially in the development of emphysema, but the underlying mechanisms by which it promotes emphysema and bronchitis in COPD is not clear.

\section{Autophagy and fibrotic airway remodeling}

The pathogenesis of COPD and asthma is typified by structural changes in the lung, collectively known as airway remodeling, which is characterized by basement membrane fibrosis, epithelial goblet cell hyperplasia, deposition of extracellular matrix proteins and smooth muscle hypertrophy ${ }^{35,36}$. Current therapies provide very limited benefit on airway remodeling ${ }^{12,37-41}$, thus identifying new drug targets that can prevent or reduce airway remodeling in asthma and COPD is vital to reverse structural changes that determines the underlying cause of the disease ${ }^{35,42}$. TGF $\beta 1$ is a well-known regulator of inflammation and fibrotic remodeling in COPD and asthma, and it is upregulated in both disease ${ }^{11}$. TGF $\beta 1$ is the most abundant isoform of the TGF- $\beta$ family and is secreted by most immune cells, including airway epithelial, smooth muscle, fibroblast and endothelial cells. TGF $\beta 1$ acts through the Smad dependent pathway and independent pathways, like mitogen activated protein kinases (MAPKs) namely p38 MAPK and c-Jun-N-terminal kinase, leading to the accumulation of extracellular matrix (ECM).

Autophagy-mediated TGF $\beta 1$-induced fibrosis plays a key role in the pathogenesis of heart and kidney diseases ${ }^{43,44}$, and recent studies in human airway smooth muscle cells have demonstrated that TGF $\beta 1$ induced autophagy is required for collagen and fibronectin production, while silencing of key autophagy-inducing proteins Atg5 and Atg7 leads to reduction in pro-fibrotic signaling 
and ECM protein release $\mathrm{e}^{45,46}$. It is now believed that increased production of matrix proteins, as seen in airway remodeling, requires huge resources of energy, which is compensated by enhanced autophagy flux within the cell ${ }^{46}$. Our own data (unpublished) demonstrates that there is a simultaneous induction of autophagy and pro-fibrotic signaling in human airway mouse models of allergic asthma. We propose that blockade of autophagy in the lungs can lead to reduction in airway fibrosis, as seen in airway remodeling in asthma and COPD. Recent observations suggest that autophagy exhibits a circadian rhythm and this rhythmic activation of autophagy is regulated by the transcription factor $\mathrm{C} / \mathrm{EBP} \beta^{47}$. These findings need to be further evaluated in the context of asthma and COPD, as circadian rhythm genes can also be a potential target to modulate autophagy ${ }^{47}$.

\section{Therapeutic strategies: Novel autophagy modulators}

The mechanistic insight of disease pathogenesis in chronic airway diseases, such as asthma and COPD, is complex. Altered structural changes in the lung correlates with poor lung function, severity of disease and response to therapy in asthma and COPD. Current therapy does not target the underlying cause/s of the disease and does not restore the structural integrity of the airways $^{12,37-41}$; therefore, novel mechanisms, such as autophagy, pose attractive therapeutic options in airway remodeling. With the emerging role of autophagy in asthma and COPD and our increased understanding in the disease pathogenesis, we believe that the autophagy pathway can be exploited for therapeutic benefit. One of the exciting features of this pathway is that it can be inhibited at several steps, including initiation and vesicle elongation, autophagosome formation and maturation, and autophagosome lysosome fusion. Emerging evidence suggests that autophagy inhibition at the very first step is beneficial in an ovalbumin-induced model of asthma in mice, where 3-methyl adenine, a class III PI3K inhibitor, reduced the expression of autophagy marker LC3B with simultaneous reduction in airway eosinophilia ${ }^{19}$. However, there is a need for more research in exploring the role of various PI3K inhibitors in the context of autophagy dependent-airway remodeling, using the most suitable models of asthma and COPD, as modulation of autophagy by the PI3K pathway can be an attractive target for both severe asthma and COPD ${ }^{48-51}$.

Bafilomycin A1 is a late phase potent inhibitor of autophagy, which acts through the inhibition of vacuolar type $\mathrm{H}^{+}$-ATPase that is present on lysosomes. Inhibition of vacuolar type $\mathrm{H}^{+}$-ATPase by bafilomycin A1 leads to acidification of lysosomes and inhibits their fusion with autophagosomes ${ }^{52}$. Previous studies also indicate that bafilomycin inhibits the infection and airway inflammation induced by rhinovirus ${ }^{53}$. Chloroquine is a well know anti-malarial and anti-rheumatoid agent, and it is also used for blocking autophagy at a late stage by lysosomal dysfunction (lysosomal lumen alkalizers ${ }^{52}$. The most important shortcoming of chloroquine is that this molecule blocks autophagy only at higher concentrations. Lys01 and Lys05 were recently developed modified versions of chloroquine, which are 10 -fold more potent in autophagy inhibition ${ }^{52,54,55}$; however these require further validation in asthma and COPD models.

Kinases, such as adenosine monophosphate activated protein kinase (AMPK) and ULK1 (mammalian orthologue of yeast protein kinase Atg1) are required for autophagy. AMPK senses nutrient deficiency and positively regulates ULK1, leading to activation of autophagy. Moreover, it has been reported that loss of either of these kinases results in defective autophagy (mitophagy) ${ }^{56}$. Modulating the AMPK-ULK1 pathway may be an option for treatment of chronic airway diseases. Further recent observations suggest that autophagy exhibits a circadian rhythm and this rhythmic activation of autophagy is regulated by the transcription factor $\mathrm{C} / \mathrm{EBP} \beta^{47}$. These findings need to be further evaluated in the context of asthma and COPD, as circadian rhythm genes can also be a potential target to modulate autophagy.

Thus, there is a need to identify the right autophagy mechanism in the progression and development of airway remodeling in asthma and COPD, which can become a realistic drug target to prevent structural changes in the lung.

\section{Conclusions and future perspectives}

Based on the current scientific data, the autophagy pathway is directly linked to asthma and COPD pathophysiology and may act as a potential contributor to fibrotic airway remodeling, as described in Figure 2. Future research should be directed towards understanding the specific pathway and the mecha-

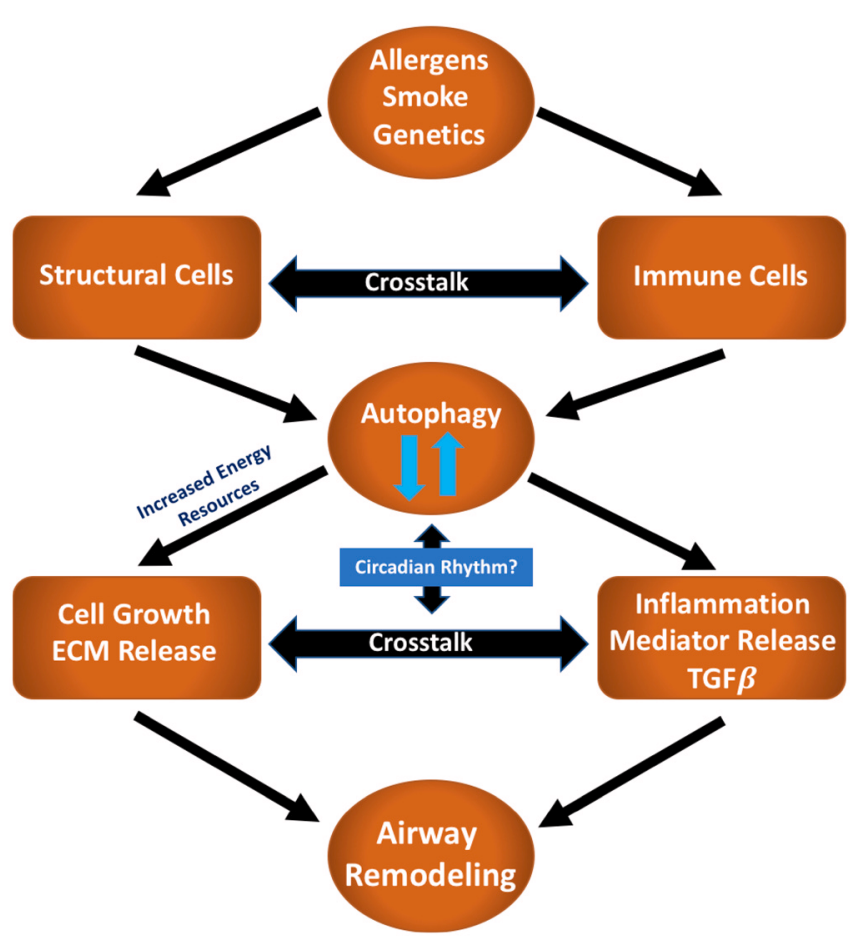

Figure 2. Autophagy mediates airway remodeling. An altered autophagy pathway is seen in response to cellular stress in asthma and chronic obstructive pulmonary disease (allergens or smoke or genetics), leading to activation and crosstalk between structural airway and immune cells. This further leads to impairment of autophagy causing degradation of intracellular constituents, providing an energy resource for ECM protein biosynthesis, and releasing mediators of inflammation and profibrotic signaling, which collectively lead to airway remodeling in the lung. Role of circadian rhythm genes in this context needs to be investigated. ECM: extracellular matrix; TGF $\beta$ : transforming growth factor-beta. 
nism/s leading to the pathophysiological activation of autophagy in disease. Efforts should be made in developing a modulator of autophagy as a new therapeutic strategy for treatment of airway remodeling in asthma and COPD. In the future, we propose to study the role of circadian rhythm genes in the activation of the autophagy pathway and understand whether modulating circadian rhythm genes, using novel small chemical compounds, has any therapeutic benefit in animal models of asthma and COPD.

Author contributions

$\mathrm{PS}, \mathrm{BO}, \mathrm{DD}, \mathrm{MH}$ conceived the plan of the review. PS and AK prepared the first draft of the manuscript. All authors were involved in the revision of the draft manuscript and have agreed to the final content.

\section{Competing interests}

No competing interests were disclosed.

\section{Grant information}

This work was supported by the Centre for Health Technologies, Chancellors Fellowship Research Program, the National Institute of Health, and the National Health and Medical Research Council.

The funders had no role in study design, data collection and analysis, decision to publish, or preparation of the manuscript.
1. Yorimitsu T, Klionsky DJ: Autophagy: molecular machinery for self-eating. Cell Death Differ. 2005; 12(Suppl 2): 1542-52. PubMed Abstract | Publisher Full Text | Free Full Text

2. Eskelinen EL, Saftig P: Autophagy: a lysosomal degradation pathway with a central role in health and disease. Biochim Biophys Acta. 2009; 1793(4): 664-73.

PubMed Abstract | Publisher Full Text

3. Klionsky DJ: Autophagy: from phenomenology to molecular understanding in less than a decade. Nat Rev Mol Cell Biol. 2007; 8(11): 931-7. PubMed Abstract | Publisher Full Text

4. Ravikumar B, Sarkar S, Davies JE, et al.: Regulation of mammalian autophagy in physiology and pathophysiology. Physiol Rev. 2010; 90(4): 1383-435. PubMed Abstract | Publisher Full Text

5. Mizushima N, Levine B, Cuervo AM, et al:: Autophagy fights disease through cellular self-digestion. Nature. 2008; 451(7182): 1069-75.

PubMed Abstract | Publisher Full Text | Free Full Text

6. Lee JA: Autophagy in neurodegeneration: two sides of the same coin. $B M B$ Rep. 2009; 42(6): 324-30. PubMed Abstract | Publisher Full Text

7. Rosenfeldt MT, Ryan KM: The multiple roles of autophagy in cancer Carcinogenesis. 2011; 32(7): 955-63. PubMed Abstract | Publisher Full Text | Free Full Text

8. Martinet W, De Meyer GR: Autophagy in atherosclerosis: a cell survival and death phenomenon with therapeutic potential. Circ Res. 2009; 104(3): 304-17. PubMed Abstract | Publisher Full Text

9. Gottlieb RA, Mentzer RM: Autophagy during cardiac stress: joys and frustrations of autophagy. Annu Rev Physiol. 2010; 72: 45-59. PubMed Abstract | Publisher Full Text | Free Full Text

10. Levine B, Mizushima N, Virgin HW: Autophagy in immunity and inflammation Nature. 2011; 469(7330): 323-35. PubMed Abstract | Publisher Full Text | Free Full Text

11. Yang YC, Zhang N, Van Crombruggen $\mathrm{K}$, et al:: Transforming growth factorbeta1 in inflammatory airway disease: a key for understanding inflammation and remodeling. Allergy. 2012; 67(10): 1193-202. PubMed Abstract | Publisher Full Text

12. Prakash YS, Halayko AJ, Gosens R, et al: An Official American Thoracic Society Research Statement: Current Challenges Facing Research and Therapeutic Advances in Airway Remodeling. Am J Respir Crit Care Med. 2017; 195(2): e4-e19.

PubMed Abstract | Publisher Full Text

13. James $\mathrm{AL}$, Elliot $\mathrm{JG}$, Jones $\mathrm{RL}$, et al: Airway smooth muscle hypertrophy and hyperplasia in asthma. Am J Respir Crit Care Med. 2012; 185(10): 1058-64. PubMed Abstract | Publisher Full Text

14. Boulieri A, Hansell A, Blangiardo M: Investigating trends in asthma and COPD through multiple data sources: A small area study. Spat Spatiotemporal Epidemiol. 2016; 19: 28-36.

PubMed Abstract | Publisher Full Text | Free Full Text

15. Poon AH, Chouiali F, Tse SM, et al:: Genetic and histologic evidence for autophagy in asthma pathogenesis. J Allergy Clin Immunol. 2012; 129(2): 569-71. PubMed Abstract | Publisher Full Text | Free Full Text

16. Poon A, Eidelman D, Laprise C, et al.: ATG5, autophagy and lung function in asthma. Autophagy. 2012; 8(4): 694-5. PubMed Abstract | Publisher Full Text
17. Caveolin-1 Protects Against Cigarette Smoking Induced Autophagic Cell Death and Emphysema in Chronic Obstructive Pulmonary Disease. In $A 13$. INSIGHTS IN COPD PATHOGENESIS. A1001.

Publisher Full Text

18. Martin LJ, Gupta J, Jyothula SS, et al:: Functional variant in the autophagyrelated 5 gene promotor is associated with childhood asthma. PLOS One. 2012; 7(4): e33454.

PubMed Abstract | Publisher Full Text | Free Full Text

19. Liu JN, Suh $\mathrm{DH}$, Trinh HK, et al.: The role of autophagy in allergic inflammation: a new target for severe asthma. Exp Mol Med. 2016; 48(7): e243.

PubMed Abstract | Publisher Full Text | Free Full Text

20. Pham DL, Ban GY, Kim SH, et al.: Neutrophil autophagy and extracellular DNA traps contribute to airway inflammation in severe asthma. Clin Exp Allergy. 2017; 47(1): 57-70.

PubMed Abstract | Publisher Full Text

21. Ban GY, Pham DL, Trinh TH, et al.: Autophagy mechanisms in sputum and peripheral blood cells of patients with severe asthma: a new therapeutic target. Clin Exp Allergy. 2016; 46(1): 48-59.

PubMed Abstract | Publisher Full Text

22. Suzuki $Y$, Maazi H, Sankaranarayanan I, et al.: Lack of autophagy induces steroidresistant airway inflammation. J Allergy Clin Immunol. 2016; 137(5): 1382-1389.e9. PubMed Abstract | Publisher Full Text | Free Full Text

23. Burgel PR, Bourdin A, Pilette $C$, et al:: [Structural abnormalities and inflammation in COPD: a focus on small airways]. Rev Mal Respir. 2011; 28(6): 749-60. PubMed Abstract | Publisher Full Text

24. Kirkham PA, Barnes PJ: Oxidative stress in COPD. Chest. 2013; 144(1): 266-73.

PubMed Abstract | Publisher Full Text

25. Koyama H, Geddes DM: Genes, oxidative stress, and the risk of chronic obstructive pulmonary disease. Thorax. 1998; 53(Suppl 2): S10-4. PubMed Abstract | Publisher Full Text | Free Full Text

26. Vij N, Chandramani-Shivalingappa P, Van Westphal C, et al.: Cigarette smokeinduced autophagy-impairment accelerates lung aging, COPD-emphysema exacerbations and pathogenesis. Am J Physiol Cell Physiol. 2018; 314(1): exacerbations and pathogen C73-C87. ajpcell.00110.2016.
PubMed Abstract | Publisher Full Text | Free Full Text

27. Tran I, Ji C, Ni I, et al:: Role of Cigarette Smoke-Induced Aggresome Formation in Chronic Obstructive Pulmonary Disease-Emphysema Pathogenesis. in Chronic Obstructive Pulmonary DiseaseAm J Respir Cell Mol Biol. 2015; 53(2): 159-73.
PubMed Abstract | Publisher Full Text | Free Full Text

28. Fujii S, Hara $\mathrm{H}$, Araya J, et al.: Insufficient autophagy promotes bronchial epithelial cell senescence in chronic obstructive pulmonary disease. Oncoimmunology. 2012; 1(5): 630-641. PubMed Abstract | Publisher Full Text | Free Full Text

29. Chen ZH, Kim HP, Sciurba FC, et al:: Egr-1 regulates autophagy in cigarette smoke-induced chronic obstructive pulmonary disease. PLoS One. 2008; 3(10): e3316.

PubMed Abstract | Publisher Full Text | Free Full Text

30. Kim HP, Wang $\mathrm{X}$, Chen $\mathrm{ZH}$, et al:: Autophagic proteins regulate cigarette smoke-induced apoptosis: protective role of heme oxygenase-1. Autophagy. 2008; 4(7): 887-95.

PubMed Abstract | Publisher Full Text

31. Lam HC, Cloonan SM, Bhashyam AR, et al:: Histone deacetylase 6-mediated 
selective autophagy regulates COPD-associated cilia dysfunction. J Clin Invest. 2013; 123(12): 5212-30

PubMed Abstract | Publisher Full Text | Free Full Text

32. Ryter SW, Choi AM: Autophagy in lung disease pathogenesis and therapeutics. Redox Biol. 2015; 4: 215-25.

PubMed Abstract | Publisher Full Text | Free Full Text

33. Zhu L, Barrett EC, Xu Y, et al:: Regulation of Cigarette Smoke (CS)-Induced Autophagy by Nrf2. PLoS One. 2013; 8(4): e55695. PubMed Abstract | Publisher Full Text | Free Full Text

34. Mizumura K, Cloonan SM, Nakahira K, et al:: Mitophagy-dependent necroptosis contributes to the pathogenesis of COPD. J Clin Invest. 2014; 124(9): 3987-4003. PubMed Abstract | Publisher Full Text | Free Full Text

35. Chung KF: The role of airway smooth muscle in the pathogenesis of airway wall remodeling in chronic obstructive pulmonary disease. Proc Am Thorac Soc. 2005; 2(4): 347-54; discussion 371-2. PubMed Abstract | Publisher Full Text | Free Full Text

36. Al-Alawi M, Hassan T, Chotirmall SH: Transforming growth factor $\boldsymbol{\beta}$ and severe asthma: a perfect storm. Respir Med. 2014; 108(10): 1409-23. PubMed Abstract | Publisher Full Text

37. Royce SG, Moodley Y, Samuel CS: Novel therapeutic strategies for lung disorders associated with airway remodelling and fibrosis. Pharmacol Ther. 2014; 141(3): 250-60

PubMed Abstract | Publisher Full Text

38. Roth M: Airway and lung remodelling in chronic pulmonary obstructive disease: a role for muscarinic receptor antagonists? Drugs. 2015; 75(1): 1-8. PubMed Abstract | Publisher Full Text

39. Pauwels B, Jonstam K, Bachert C: Emerging biologics for the treatment of chronic rhinosinusitis. Expert Rev Clin Immunol. 2015; 11(3): 349-61. PubMed Abstract | Publisher Full Text

40. Kume H, Fukunaga K, Oguma T: Research and development of bronchodilators for asthma and COPD with a focus on $G$ protein/ $K_{c a}$ channel linkage and $\beta_{2}-$ adrenergic intrinsic efficacy. Pharmacol Ther. 2015; 156: 75-89. PubMed Abstract | Publisher Full Text

41. Pelaia G, Vatrella A, Maselli R: The potential of biologics for the treatment of asthma. Nat Rev Drug Discov. 2012; 11(12): 958-72. PubMed Abstract | Publisher Full Text

42. Soltani A, Walters EH, Reid DW, et al:: Inhaled corticosteroid normalizes some but not all airway vascular remodeling in COPD. Int $J$ Chron Obstruct Pulmon Dis. 2016; 11: 2359-2367.

PubMed Abstract | Publisher Full Text | Free Full Text

43. Ghavami S, Cunnington RH, Gupta S, et al: Autophagy is a regulator of TGF- $\beta 1$ induced fibrogenesis in primary human atrial myofibroblasts. Cell Death Dis. 2015; 6: e1696.

PubMed Abstract | Publisher Full Text | Free Full Text

44. Ding $Y$, Choi ME: Regulation of autophagy by TGF- $\beta$ : emerging role in kidney fibrosis. Semin Nephrol. 2014; 34(1): 62-71.

PubMled Abstract | Publisher Full Text | Free Full Text

45. Autophagy Regulates Tgf-Beta1 Induced Fibrosis In Human Airway Smooth

Muscle Cells. In A67. SURVIVOR-RCMB: AUTOPHAGY, SENESCENCE, AND

SURVIVAL. A2110.

Publisher Full Text

46. Zeki AA, Yeganeh B, Kenyon NJ, et al:: Autophagy in airway diseases: a new

frontier in human asthma? Allergy. 2016; 71(1): 5-14.

PubMed Abstract | Publisher Full Text | Free Full Text

47. Ma D, Lin JD: Circadian regulation of autophagy rhythm through transcription factor C/EBPß. Autophagy. 2012; 8(1): 124-5.

PubMed Abstract | Publisher Full Text | Free Full Text

48. Wu YT, Tan HL, Shui G, et al.: Dual role of 3-methyladenine in modulation of autophagy via different temporal patterns of inhibition on class I and III phosphoinositide 3-kinase. J Biol Chem. 2010; 285(14): 10850-61.

PubMed Abstract | Publisher Full Text | Free Full Text

49. Dowdle WE, Nyfeler B, Nagel J, et al:: Selective VPS34 inhibitor blocks autophagy and uncovers a role for NCOA4 in ferritin degradation and iron homeostasis in vivo. Nat Cell Biol. 2014; 16(11): 1069-79.

PubMed Abstract | Publisher Full Text

50. Ronan B, Flamand O, Vescovi L, et al.: A highly potent and selective Vps34 inhibitor alters vesicle trafficking and autophagy. Nat Chem Biol. 2014; 10(12): 1013-1019.

PubMed Abstract | Publisher Full Text

51. Stark AK, Sriskantharajah S, Hessel EM, et al.: PI3K inhibitors in inflammation, autoimmunity and cancer. Curr Opin Pharmacol. 2015; 23: 82-91. PubMed Abstract | Publisher Full Text | Free Full Text

52. Yang YP, Hu LF, Zheng HF, et al.: Application and interpretation of current autophagy inhibitors and activators. Acta Pharmacol Sin. 2013; 34(5): 625-635. PubMed Abstract | Publisher Full Text | Free Full Text

53. Yamaya M, Sasaki H: [The pathogenesis and therapy of virus infection-induced senile bronchial asthma]. Nihon Ronen Igakkai Zasshi. 2000; 37(6): 464-8. PubMed Abstract | Publisher Full Text

54. Amaravadi RK, Winkler JD: Lys05: a new lysosomal autophagy inhibitor. Autophagy. 2012; 8(9): 1383-4.

PubMed Abstract | Publisher Full Text | Free Full Text

55. McAfee Q, Zhang Z, Samanta A, et al.: Autophagy inhibitor Lys 05 has singleagent antitumor activity and reproduces the phenotype of a genetic autophagy deficiency. Proc Natl Acad Sci U S A. 2012; 109(21): 8253-8. PubMed Abstract | Publisher Full Text | Free Full Text

56. Egan DF, Shackelford DB, Mihaylova MM, et al:: Phosphorylation of ULK1 (hATG1) by AMP-activated protein kinase connects energy sensing to mitophagy. Science. 2011; 331(6016): 456-61.

PubMed Abstract | Publisher Full Text | Free Full Text 


\section{Open Peer Review}

\section{Current Peer Review Status:}

\section{Version 2}

Reviewer Report 04 July 2018

https://doi.org/10.5256/f1000research.15658.r34897

(C) 2018 Roscioli E. This is an open access peer review report distributed under the terms of the Creative Commons Attribution License, which permits unrestricted use, distribution, and reproduction in any medium, provided the original work is properly cited.

\section{Eugene Roscioli}

Royal Adelaide Hospital - Hanson Institute, University of Adelaide, Adelaide, SA, Australia

As the initial reviewer, I am delighted with the level of corrections the author group has made to improve their review article. Further, I'd like to amend one statement and say a fine achievement for the Sharma group, in collaboration with Prof Oliver.

Competing Interests: No competing interests were disclosed.

I confirm that I have read this submission and believe that I have an appropriate level of expertise to confirm that it is of an acceptable scientific standard.

\section{Version 1}

Reviewer Report 04 May 2017

\section{https://doi.org/10.5256/f1000research.12123.r21520}

(C) 2017 Sohal S. This is an open access peer review report distributed under the terms of the Creative Commons Attribution License, which permits unrestricted use, distribution, and reproduction in any medium, provided the original work is properly cited.

\section{Sukhwinder Singh Sohal}

Faculty of Health, School of Health Sciences, University of Tasmania, Launceston, Tasmania, Australia

\section{Summary -}

The current manuscript has reviewed the literature on relationship between autophagy and 
airway fibrosis in chronic lung disease, especially asthma and COPD. This topic is of great interest and very little work has been done to understand the underlying mechanisms. I think this article is a timely reminder and will stimulate research into this area, which is much needed. Overall, this a well presented article but I have some suggestions, which will enhance readability and understanding on the diseases discussed.

\section{Major comments -}

1. Before authors go into the details for role of autophagy in asthma/remodeling, I think they need to add a separate section on airway remodeling and autophagy first.

2. Please list the airway remodeling changes described in asthma so far and then discuss which might be related to autophagy.

3. I think authors need to add a reference if there is any work done on fibroblast populations in asthma to make the case for fibrosis or suggest as potential future work.

4. Similar changes I think need to be made for the COPD section, especially listing airway remodeling changes described so far, for example Rbm fragmentation, vascularity, epithelial mesenchymal transition (EMT) etc.

5. Authors stated in the evidence for autophagy in COPD section that major features are emphysema and chronic bronchitis. I think it is very important to describe small airway destructive pathology in COPD. The classic fixed airflow obstruction described in COPD comes from the small airways. These airways are destroyed by up to nearly $40 \%$ well before the diagnosis of COPD. So damage starts quite early on and it is this site where fibrosis really occurs and EMT is central to this. Airway disease is the primary phenomenon in COPD.

6. EGFR has also been regarded as one of the important drivers of airway remodeling in asthma and COPD, that needs to be discussed.

Is the topic of the review discussed comprehensively in the context of the current literature?

Yes

Are all factual statements correct and adequately supported by citations? Yes

Is the review written in accessible language?

Yes

Are the conclusions drawn appropriate in the context of the current research literature? Yes

Competing Interests: No competing interests were disclosed.

I confirm that I have read this submission and believe that I have an appropriate level of expertise to confirm that it is of an acceptable scientific standard. 
Author Response 20 Mar 2018

Pawan Sharma, Thomas Jefferson University, USA

Reviewer 3: We thank reviewer for constructive feedback. Reviewers' comments are addressed one by one below (comments in italics followed by our response).

C1: Before authors go into the details for role of autophagy in asthma/remodelling, I think they need to add a separate section on airway remodelling and autophagy first.

R1: We have now added this to the text.

C2: Please list the airway remodelling changes described in asthma so far and then discuss which might be related to autophagy.

R2: We have now added new text to the MS.

C3: I think authors need to add a reference if there is any work done on fibroblast populations in asthma to make the case for fibrosis or suggest as potential future work.

R3: We have added references related to fibroblasts and potential future direction in this area.

C4: Similar changes I think need to be made for the COPD section, especially listing airway remodelling changes described so far, for example Rbm fragmentation, vascularity, epithelial mesenchymal transition (EMT) etc.

R4: We have now modified the text and added these suggestions as well.

C5: Authors stated in the evidence for autophagy in COPD section that major features are emphysema and chronic bronchitis. I think it is very important to describe small airway destructive pathology in COPD. The classic fixed airflow obstruction described in COPD comes from the small airways. These airways are destroyed by up to nearly $40 \%$ well before the diagnosis of COPD. So, damage starts quite early on and it is this site where fibrosis really occurs and EMT is central to this. Airway disease is the primary phenomenon in COPD.

R5: These are valid points made by the reviewers, we have modified the text in the MS.

C6: EGFR has also been regarded as one of the important drivers of airway remodeling in asthma and COPD, that needs to be discussed.

R6: We agree that EGFR is an important player in driving airway remodeling but the current review focusses on autophagy pathway and how it is linked to airway fibrosis.

Competing Interests: none

Reviewer Report 02 May 2017

https://doi.org/10.5256/f1000research.12123.r22182

(C) 2017 Wang K. This is an open access peer review report distributed under the terms of the Creative Commons Attribution License, which permits unrestricted use, distribution, and reproduction in any medium, provided the original work is properly cited. 


\section{Kimberley C.W. Wang}

Telethon Kids Institute, Subiaco, WA, Australia

Summary:

This review clearly demonstrates the need for more studies investigating the role of autophagy in respiratory disease. It is good that the authors added some unpublished data into the review article as support of evidence.

Major comments:

1. Figure 2 can be improved. Eg: at the arrow between Autophagy and Cell Growth/ECM release, the authors can add the words increase energy resource so the readers understand the association between Autophagy and Cell Growth/ECM release. Authors should consider adding 'Genetics' into the figure. The authors could add 'circadian rhythm' into the figure with a '?' to show that it is a factor for further investigation.

2. For the collectively structural changes of airway remodeling, please include smooth muscle hyperplasia (James et al. 2012; Am J Respir Crit Care Med).

3. In the autophagy and fibrotic airway remodelling section, the paragraphs could be rearranged. Eg do not split TGFb1 between the paragraphs. The section about circadian rhythm seems to be a better fit in the Therapeutic strategies: Novel autophagy modulators section, as it is something to further evaluate as a potential target.

4. Are there any genetic component as evidence of autophagy in COPD? For example: Chen et al. 2015; J Formos Med Assoc.

5. Should have a reference for the sentence regarding TGFb1 leads to accumulation of ECM. ECM could be abbreviate earlier in the article.

Is the topic of the review discussed comprehensively in the context of the current literature?

Yes

Are all factual statements correct and adequately supported by citations?

Yes

Is the review written in accessible language?

Yes

Are the conclusions drawn appropriate in the context of the current research literature? Yes

Competing Interests: No competing interests were disclosed.

I confirm that I have read this submission and believe that I have an appropriate level of 


\section{expertise to confirm that it is of an acceptable scientific standard.}

Author Response 20 Mar 2018

Pawan Sharma, Thomas Jefferson University, USA

Reviewer $\mathbf{2}$ We thank reviewer for constructive feedback. Reviewers' comments are addressed one by one below (comments in italics followed by our response).

C1: Figure 2 can be improved. Eg: at the arrow between Autophagy and Cell Growth/ECM release, the authors can add the words increase energy resource, so the readers understand the association between Autophagy and Cell Growth/ECM release. Authors should consider adding 'Genetics' into the figure. The authors could add 'circadian rhythm' into the figure with a '?' to show that it is a factor for further investigation.

R1: We have modified the figure accordingly.

C2: For the collectively structural changes of airway remodeling, please include smooth muscle hyperplasia (James et al. 2012; Am J Respir Crit Care Med).

R2: We have now added this with the reference.

C3: In the autophagy and fibrotic airway remodelling section, the paragraphs could be rearranged. Eg do not split TGFb1 between the paragraphs. The section about circadian rhythm seems to be a better fit in the Therapeutic strategies: Novel autophagy modulators section, as it is something to further evaluate as a potential target.

R3: It has been moved to the section on novel autophagy modulators.

C4: Are there any genetic component as evidence of autophagy in COPD? For example: Chen et al. 2015; J Formos Med Assoc.

R4: Not as far as we know.

C5: Should have a reference for the sentence regarding TGFb1 leads to accumulation of ECM. ECM could be abbreviated earlier in the article

R5: Reference added.

Competing Interests: None

Reviewer Report 10 April 2017

https://doi.org/10.5256/f1000research.12123.r21469

(C) 2017 Roscioli E. This is an open access peer review report distributed under the terms of the Creative Commons Attribution License, which permits unrestricted use, distribution, and reproduction in any medium, provided the original work is properly cited.

\section{Eugene Roscioli}

Royal Adelaide Hospital - Hanson Institute, University of Adelaide, Adelaide, SA, Australia 


\section{Summary statement}

Kota et al. present an interesting and challenging subject for review - the interrelationship between autophagy in the context of airway diseases that exhibit airway remodelling as a major pathological feature. Challenging because we still have a lot to learn about both airway remodelling, and indeed the diseases such as asthma and COPD that potentiate fibrotic airway changes, and further still the contribution of increased or blocked autophagy as a driver, or parallel phenomena in this scenario. Overall they provide a needed and good start to the discussion, that will no doubt pioneer further debate in these areas off airway pathobiology. Hence, one leaves this review thinking about the link between fibrosis and autophagy, but also, wondering what insight they gained to direct new lines of inquiry.

\section{Major comments}

As stated, this is by no means an easy literature review to compose. At first one would think this is due to limited publication of such studies. However, a PubMed search using "Fibrosis[Title] and Autophagy[Title]", show there are 83 hits for this query. While the vast majority are not respiratory in nature, it would be beneficial if Kota et al. could use mechanistic insights from other diseases to draw hypothetical parallels with the situation that may be occurring in the airways, which they elude to in paragraph 2 under the heading "Autophagy and fibrotic airway remodelling", but little supposition is made in regards to this thereafter. Indeed, this paragraph is possibly the only one which directly address the subject matter stated by the title. Refreshingly however, they generously state new unpublished finding (on three occasions) from their laboratory which provides insight for the reader and which have the potential to direct further lines if understanding.

A current question for autophagy is: is it a block in autophagic flux leading to (or contributing to) the cellular dyshomeostasis, or is autophagy increased because it is unable to manage the protracted/chronic disease stressors? While Kota et al. touch upon this question for COPD, and correctly state that there is significant conjecture with regards to this, subsequent discussion mainly lent to the increased autophagy scenario, with an extended discussion with regards to cilia (ciliophagy). Indeed, we now know the relationship between cilia and autophagy is a complex dual interaction whereby they foster each other's activity/generation rather than a one way situation where increased autophagy leads to the degradation of cilia (Pampliega et al., 2016). Hence, some new insights/thoughts which could weigh into the autophagic flux vs. increased autophagy debate would be welcomed.

Further, airway fibrosis occurs as a result of the chronic inflammation (in addition to e.g. altered smooth muscle-epithelia interactions, between themselves and the inflammatory cells), while autophagy is known to be an anti-inflammatory mechanism. Hence, beyond TGF $\beta$, some insights into how the dysregulation of autophagy leads to fibrosis driven by complex inflammatory changes at the airways would have been informative.

Hence, while this review most certainly warrants publication, and marks yet another achievement for the Oliver laboratory, the informed reader may ask for more than the start of the dialogue presented in this particular review.

\section{Minor comments}

The manner of composition on occasions lacks maturity. For example, "ATG5 encodes a protein of 
276 amino acids", is not needed in a review article. The chronological presentation of concepts/studies, should be forfeited to a style of writing that groups and discusses processes to illustrate a pattern of phenomena that helps orient/inform the reader. Avoid using definite statements such as "clearly indicates", particularly in a review, and especially in areas where we have so much more to learn such as is the case for chronic lung disease and autophagy. Finally, approximately one third of the 55 references are review articles.

\section{References}

1. Pampliega O, Cuervo AM: Autophagy and primary cilia: dual interplay.Curr Opin Cell Biol. 2016; 39: 1-7 PubMed Abstract | Publisher Full Text

Is the topic of the review discussed comprehensively in the context of the current literature?

Yes

Are all factual statements correct and adequately supported by citations?

Yes

Is the review written in accessible language?

Yes

Are the conclusions drawn appropriate in the context of the current research literature? Yes

Competing Interests: No competing interests were disclosed.

I confirm that I have read this submission and believe that I have an appropriate level of expertise to confirm that it is of an acceptable scientific standard.

Author Response 20 Mar 2018

Pawan Sharma, Thomas Jefferson University, USA

Reviewer 1: We thank reviewer for the constructive feedback. Reviewers' comments are addressed one by one below (comments in italics followed by our response).

C1: As stated, this is by no means an easy literature review to compose. At first one would think this is due to limited publication of such studies. However, a PubMed search using "Fibrosis[Title] and Autophagy[Title]", show there are 83 hits for this query. While the vast majority are not respiratory in nature, it would be beneficial if Kota et al. could use mechanistic insights from other diseases to draw hypothetical parallels with the situation that may be occurring in the airways, which they elude to in paragraph 2 under the heading "Autophagy and fibrotic airway remodelling", but little supposition is made in regard to this thereafter. Indeed, this paragraph is possibly the only one which directly address the subject matter stated by the title. Refreshingly however, they generously state new unpublished finding (on three occasions) from their laboratory which provides insight for the reader and which have the potential to direct further lines if understanding. 
R1: We agree with the reviewer about the complexity of the topic being reviewed. However, we would like to state that this mini-review is focussed on "lung-related" fibrotic changes in asthma and COPD. We haven't discussed other lung diseases such because the autophagy pathway is quite distinct in those diseases which will make it difficult to bring them under the same category. This review has tried to discuss the dysregulated autophagy pathway in asthma and COPD pathology as literature suggests there are some parallels in autophagy signalling mechanisms. Further, TGFbeta driven fibrotic changes that are dependent and mediated through autophagy are discussed in this review which also occur in other organs such as liver and kidney fibrosis.

C2. A current question for autophagy is: is it a block in autophagic flux leading to (or contributing to) the cellular dyshomeostasis, or is autophagy increased because it is unable to manage the protracted/chronic disease stressors? While Kota et al. touch upon this question for COPD, and correctly state that there is significant conjecture with regards to this, subsequent discussion mainly lent to the increased autophagy scenario, with an extended discussion with regards to cilia (ciliophagy). Indeed, we now know the relationship between cilia and autophagy is a complex dual interaction whereby they foster each other's activity/generation rather than a oneway situation where increased autophagy leads to the degradation of cilia (Pampliega et al., 2016). Hence, some new insights/thoughts which could weigh into the autophagic flux vs. increased autophagy debate would be welcomed.

R2. Reviewer has asked a very interesting question with relevance to autophagy: whether it is being blocked or increased during disease pathology. We believe it is too early to say that autophagy flux is blocked or there is a net increase in autophagy that could lead to disease pathology. Published literature in COPD suggests that that there is an increase in autophagy in disease, and this has been also demonstrated in the cigarette smoke-induced experimental COPD models with additional increase in ciliophagy contributing to reduced mucus clearance (Choi's group). In asthma, it is not yet clear whether there is a block in autophagy flux or there is a net increase in autophagy, though recent data demonstrate increase number of autophagosomes in asthma that associates with lung function and ECM protein in humans (Poon et al). In experimental models of allergic asthma there is an evidence to believe that autophagy is increased in severe asthma models and inhibition of autophagy in vivo may be a viable option.

C3. Further, airway fibrosis occurs as a result of the chronic inflammation (in addition to e.g. altered smooth muscle-epithelia interactions, between themselves and the inflammatory cells), while autophagy is known to be an anti-inflammatory mechanism. Hence, beyond TGF $\beta$, some insights into how the dysregulation of autophagy leads to fibrosis driven by complex inflammatory changes at the airways would have been informative.

R3. We agree with the reviewer that there are complex cell-cell interactions and multitude of signalling pathways which eventually contributes to structural changes in the airways. Keeping in mind the scope of this review we have focussed on TGF $\beta$-dependent mechanisms that are related to the activation of autophagy in the lung. We have now added text to the MS to reflect these changes.

C4. The manner of composition on occasions lacks maturity. For example, "ATG5 encodes a protein of 276 amino acids", is not needed in a review article. The chronological presentation of concepts/studies, should be forfeited to a style of writing that groups and discusses processes to 
illustrate a pattern of phenomena that helps orient/inform the reader. Avoid using definite statements such as "clearly indicates", particularly in a review, and especially in areas where we have so much more to learn such as is the case for chronic lung disease and autophagy. Finally, approximately one third of the 55 references are review articles.

R4: We have now modified the text in the MS to reflect these changes.

Competing Interests: None

The benefits of publishing with F1000Research:

- Your article is published within days, with no editorial bias

- You can publish traditional articles, null/negative results, case reports, data notes and more

- The peer review process is transparent and collaborative

- Your article is indexed in PubMed after passing peer review

- Dedicated customer support at every stage

For pre-submission enquiries, contact research@f1000.com 